\title{
Har integrert terapi ved psykose og rusmisbruk effekt?
}

\author{
Motiverende intervju, kombinert med \\ kognitiv atferdsbehandling, reduserer \\ ikke forekomsten av reinnleggelse \\ eller død hos rusavhengige personer \\ med psykose.
}

Både motiverende intervju og kognitiv atferdsbehandling er vist å ha effekt på ruslidelser, og kognitiv atferdsbehandling er vist å ha effekt på symptomer ved psykoser. Nå har engelske forskere undersøkt om denne typen behandling har positiv virkning ved psykose og samtidig rusmisbruk (1).

I en randomisert studie deltok 327 personer med diagnosen schizofreni, schizofreniform lidelse eller schizoaffektiv lidelse og samtidig rusavhengighet eller rusmisbruk. Intervensjonen var integrert motive- rende intervju og individuell kognitiv atferdsterapi, i tillegg til standardbehandling. Intervensjonen hadde ingen positiv effekt på sykehusinnleggelser eller død etter 24 måneder og heller ikke på hyppigheten av misbruk, sykdomssymptomer eller funksjonsevne. Men motivasjonen for å endre rusatferden ble styrket, og det daglige forbruket av rusmidler gikk ned i intervensjonsperioden.

- Resultatene er isolert sett skuffende, sier professor Ingrid Melle ved Enhet for psykoseforskning, Oslo universitetssykehus. Ut fra resultatene fra en tidligere og mindre studie fra samme gruppe og som viste positiv effekt, er funnene overraskende.

- Denne nye studien hadde med flere pasienter uten nær familie og en større andel pasienter med samtidig misbruk av flere rusmidler. I forhold til den første stu- dien var tilbakefallsrisikoen i gruppen med standardbehandling vesentlig lavere. Dette kan skyldes at en del av de aktive elementene $\mathrm{i}$ behandlingsopplegget er blitt en del av standardbehandlingen. Dermed er det vanskeligere å vise klare forskjeller mellom intervensjonene, sier Melle.

\section{Trine B. Haugen}

trine.b.haugen@hf.hio.no

Tidsskriftet

\section{Litteratur \\ 1. Barrowclough C, Haddock G, Wykes T et al. Inte- grated motivational interviewing and cognitive behavioural therapy for people with psychosis and comorbid substance misuse: randomised controlled trial. BMJ 2010; 341: c6325.}

\section{Rotasjon av aktinfilamenter under elongering}

Eukaryote celler avhenger av filamenter av aktinprotein for bevegelse og fysisk integritet. Forminer er en gruppe proteiner som elongerer aktinfilamenter og deltar blant annet i celledeling, cellemigrasjon og intracellulær transport. Nå har japanske forskere utviklet en metode for å visualisere den roterende bevegelsen til aktinfilamentene når de vokser fra immobiliserte forminproteiner (Science 2010; 331: 80-3).

Studien bekrefter at aktin-elongering er koblet til en roterende bevegelse av filamentene og viser heliksrotasjon av formin langs et aktinfilament. Resultatene kan bidra med kunnskap for å forstå hvordan forminene kan overføre aktin-generert kraft til andre cellulære strukturer.

\section{Kosttilskudd \\ mot kardiovaskulær sykdom?}

Studier har antydet en invers assosiasjon mellom kardiovaskulær sykdom og plasmanivåer av B-vitaminer og omega-3-fettsyrer. NNå har franske forskere i randomiserte studier undersøkt om kosttilskudd med disse vitaminene og fettsyrene kan forebygge kardiovaskulære episoder hos pasienter som tidligere har hatt iskemisk hjertesykdom eller slag (BMJ 2010; 341: c6273).

Tilskudd av folat, vitamin B6 og vitamin B12 senket homocysteinkonsentrasjonene i plasma med $19 \%$. Plasmakonsentrasjonene av omega-3-fettsyrer økte med 37\% ved inntak av disse fettsyrene. Imidlertid hadde ikke kosttilskuddene signifikant effekt på alvorlige kardiovaskulære episoder.

\section{Akupunktur kan hjelpe mot postoperativt oppkast}

\section{Akupunktur under og akupressur etter operasjon virker forebyggende mot postoperativt oppkast hos barn og bør vurderes hos alle kirurgiske pasienter.}

Studien, som ble utført ved Lovisenberg Diakonale Sykehus i Oslo, omfattet 154 barn (1). Effekten av peroperativ akupunktur og postoperativ akupressur ble kontrollert opp mot optimal konvensjonell behandling. Akupunkturpunktet som ble stimulert, var pericardium 6 på begge underarmer. Det var ingen bivirkninger av nålebehandlingen, bortsett fra at noen få barn klaget over kløe eller stramt armbånd. Studien inngikk i den daglige rutinen ved dagkirurgisk avdeling uten bruk av ekstra ressurser.

Peroperativ akupunktur og postoperativ akupressur reduserte forekomsten av postoperativt oppkast ved tonsillektomi og adenotomi; $47 \%$ av barna i akupunkturgruppen versus $66 \%$ av de andre hadde postoperativt oppkast $(p=0,015)$. Jenter, de minste barna og barn med mindre uttalte plager responderte spesielt godt på behandlingen.

Akupunktur og akupressur bør vurderes som standard profylakse mot postoperativt oppkast hos barn som gjennomgår tonsillektomi og adenotomi. Liknende effekter

er også sett ved kvalme og brekninger hos voksne. Man er i gang med en

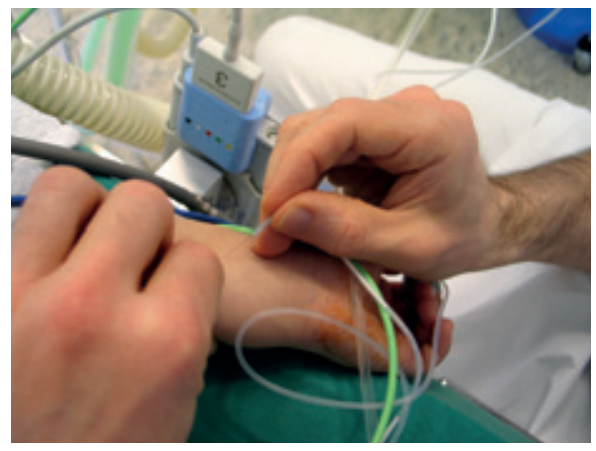

Illustrasjonsfoto Ingrid Liodden

oppfølgingsstudie der akupunktur og akupressur tilbys alle pasienter som skal til kirurgisk behandling.

\section{Arne Johan Norheim}

arne.johan.norheim@hlkbb.no

Nasjonalt forskningssenter innen komplementær og alternativ medisin (NAFKAM)

Universitetet i Troms $\emptyset$

og

Vitalisklinikken

Harstad

Litteratur

1. Liodden I, Howley M, Grimsgaard AS et al. Perioperative acupuncture and postoperative acupressure can prevent postoperative vomiting following paediatric tonsillectomy or adenoidectomy: a pragmatic randomised controlled trial. Acupunct Med 2010; doi: 10.1136/aim.2010.002915. 